\title{
K otázke česko-slovenskej vzájomnosti u Jána Čajaka
}

\author{
Zuzana Čížiková (Belehrad)
}

\begin{abstract}
Abstrakt
Štúdia približuje názory na česko-slovenskú vzájomnost' slovenského realistického spisovatel'a Jána Čajaka (1863-1944), v ktorých sa odzrkadl'uje snaha dolnozemského zaznávaného autora nepretrhnút väzby so slovenským a českým kultúrnym prostredím. Čajak zastával stanovisko, že Slováci a Česi sa v danom geopolitickom priestore Európy so silnejúcimi nacionalistickými tendenciami udržia len pestovaním a zvel'ad'ovaním česko-slovenskej vzájomnosti. Vzájomnost' vnímal ako národnú jednotu - kultúrnu, osvetovú a hospodársku spoluprácu dvoch bratských národov. V otázke jazyka sa priklonil k zástancom Štúrovej jazykovej „odluky“, a to z ideových a pragmatických dôvodov, aj pod vplyvom hlasistickej ideológie. Nevylučoval však možnost' jazykového zbliženia, resp. splynutia v budúcnosti, hoci sa mu to zdalo nemožné.
\end{abstract}

\section{Kl'účové slová}

česko-slovenská vzájomnost'; Ján Čajak; Karel Kálal; korešpondencia

\section{Abstract \\ The Issue of Czech-Slovak Relations Viewed by Ján Čajak}

This study illustrates the image of the Czech-Slovak relation by a Slovak realism writer Ján Čajak (1863-1944), reflecting the strength of the 'Low land' author, who did not cut the strings with the Slovak and Czech cultures. He believed that in given geopolitical space in Europe, with the growing nationalistic tendencies, Czechs and Slovaks could survive only by cherishing and strengthening their mutual relations. Čajak observed the relations as a national unity - cultural, educational and economic cooperation of two peoples. In terms of the languages, he supported the representatives of Štúr's linguistic 'decision' for both ideological and pragmatic reasons, and under the influence of a vocal ideology. Although it seemed impossible, Čajak did not reject the idea of languages becoming closer, i.e. integrated in future.

\section{Key words}

Czech-Slovak relations; Ján Čajak; Karel Kálal; correspondence 


\section{Osobnost' a dielo Jána Čajaka}

Slovenského dolnozemského spisovatel’a a národovca Jána Čajaka (1863-1944) zarad’uje literárna história a kritika do druhého sledu slovenských realistických spisovatelov, resp. do generácie neskorého realizmu. ${ }^{1}$ Čajakova literárna tvorba a osvetová činnost̉ je prepojená s jeho životnými osudmi: v detstve ho formovala generácia romantikov (narodil sa v rodine štúrovského básnika Janka Čajaka, po jeho smrti ho ako otčim vychovával Pavol Dobšinský, známy zberatel l’udových rozprávok), v rokoch dospievania ho zasiahla silná mad’arizácia (ako národne zmýšlajúci študent bol vylúčený z učitel’skej prípravky v Lučenci i bratislavskej evanjelickej teologickej fakulty). Napokon sa usadil ako učitel' medzi dolnozemskými Slovákmi v Báčke, najprv v Selenči (od roku 1893) a potom v Petrovci (od roku 1899, tam aj v roku 1944 zomrel), kde sa naplno rozvinula jeho osvetová, kultúrna a literárna činnost. ${ }^{2}$

Čajakova literárna tvorba tematicky, motivicky i poetologicky nadväzuje na zakladatel'skú generáciu slovenského realizmu, čo sa najvýraznejšie prejavuje v románe Rodina Rovesných (1909). Sformuloval v ňom - čiastočne v epigónskej nadväznosti na hlavného ideológa slovenského realizmu Svetozára Hurbana Vajanského - vlastnú predstavu o podobe národného programu. ${ }^{3}$ Tento jeho spoločenský román, ako konštatovala Dana Hučková, „mal byt realistickým odrazom skutočnosti, aktuálnou reakciou na spoločenské, hospodárske, politické a morálne problémy doby a slovenského národa v nej“. ${ }^{4} \mathrm{~V}$ porovnaní s románom je však omnoho významnejšia a podnetnejšia, najmä pre d’alší vývin slovenskej vojvodinskej prozaickej tvorby, Čajakova dedinská realistická poviedka. Slovenský vojvodinský literárny historik Ján Kmet vymedzil jej štyri modifikované podoby: faktografickú, didaktickú, naturalistickú a humoristickú. ${ }^{5}$ Podl'a generačne mladšieho, štrukturalisticky orientovaného vojvodinského literárneho vedca Michala Harpáňa je ovela dôležitejšie ustanovenie typologického variantu slovenskej vojvodinskej dolnozemskej prózy, ktorý sa odvíja práve od prózy J. Čajaka: „Existuje čajakovský model rozprávania, ktorý je označením prózy s dedinskou dolnozemskou tematikou, využívajúcou prvky lokálneho koloritu, humoristického prifarbenia na-

1 Porov. ŠMATLÁK, Stanislav: Dejiny slovenskej literatúry II. Bratislava: Národné literárne centrum, 1999, s. 272-273; PIŠÚT, Milan a kol.: Dejiny slovenskej literatúry. Bratislava: Obzor, 1984, s. 396-399; SEDLÁK, Imrich a kol.: Dejiny slovenskej literatúry I. Martin - Bratislava: Matica slovenská - Literárne informačné centrum, 2009, s. 511-512; ČEPAN, Oskár: Stimuly realizmu. Bratislava: Tatran, 1984, s. 45.

2 Do literatúry vstúpil až v zrelom veku, ako 40-ročný uverejnil svoju prvú prózu Predaj hory (1903), nasledovali knihy Tri rozprávky (1907), Pred oltárom (1908), Suchoty (1907), Jožkova svadba a iné rozprávky (1913) a iné.

3 Podla Čajaka má pri riešení národnej otázky patrit’ prvenstvo strednej vrstve - podnikatel'skej a remeselnícko-obchodníckej; v dobovom kontexte román naznačoval oneskorený vstup do uvedenej literárno-umeleckej polemiky, ale ako vidiet’ z novších výskumov, v kontexte žánru spoločenského románu na rozhraní 19. a 20. storočia má jeho vydanie svoje opodstatnenie. Bližšie pozri HUČKOVÁ, Dana: Úsilie o autorskú osobitost’v kontexte tradície žánru (Ján Čajak: Rodina Rovesných). Slovenská literatúra 59, 2012, č. 3, s. 217229; ČÍŽIKOVÁ, Zuzana: Slovenská vojuodinská próza: od epigónstva po paródiu. In: Imitácia - alúzia - plagiát. Nitra: Univerzita Konštantína Filozofa v Nitre, Filozofická fakulta, 2014, s. 38-49.

4 HUČKOVÁ, Dana: Úsilie o autorskú osobitost’v kontexte tradície žánru (Ján Čajak: Rodina Rovesných). Slovenská literatúra 59, 2012, č. 3, s. 219.

5 KMEŤ, Ján: Čajakova umelecká osobnost’. In: KMEŤ, Ján: Pohlady a portréty. Petrovec: Obzor, 1963, s. 37-58. 
rácie, trochu naturalistickej charakterizácie postáv, s výraznejším či menej výrazným tendenčným postojom autora. "6 $\mathrm{Na}$ tento variant potom nadväzovali mnohí prozaici povojnovej slovenskej vojvodinskej literatúry. Čajakov monografista Alexander Šimkovič takisto vysoko hodnotil prózy s dolnozemskou tematikou, no s výhradou, že v celoslovenskom kontexte išlo už v dobe vzniku o anachronizmus a postupné vyústenie do provincializmu. ${ }^{7}$

Kým prvé Čajakovo tvorivé obdobie je v znamení intenzívnej a v mnohom i jeho vrcholnej literárnej tvorby (v období 1903-1913), po prevrate v roku 1918 v literárnej tvorbe stagnuje, ale o to intenzívnejšie sa (najmä v dvadsiatych a tridsiatych rokoch) zapája do spoločenského a kultúrneho diania slovenskej národnostnej menšiny v novoutvorenom Královstve Srbov, Chorvátov a Slovincov, kde v tom čase patril k vedúcim a mienkotvorným spoločensko-kultúrnym činitelom. ${ }^{8}$ Navonok akoby zrástol so svojím novým domovom, no dobová korešpondencia odhal'uje, že sa pokúšal vrátit na Slovensko, ale nepodarilo sa mu to. ${ }^{9}$

\section{Korešpondencia Jána Čajaka}

Doteraz uverejnená Čajakova korešpondencia ${ }^{10}$ svedčí o jeho rozsiahlom písomnom styku s mnohými kl’účovými osobnostami slovenského, českého i srbského národného a literárneho života. Zo Slovákov boli adresátmi jeho listov napr. Jozef Škultéty, Štefan Krčméry, Vladimír Hurban Vladimírov, Milan Hodža, Ján Vladimír Ormis, z Čechov generačný kritik slovenskej moderny František Votruba, Adolf Heyduk, Albert Pražák a Emil Edgar, zo Srbov okrem iných Risto Kovijanić a Marko Maletin. Cenným objavom sú listy Jána Čajaka českým literátom a kultúrnym pracovníkom, ktoré sú uložené v Literárnom archíve Památníku národního písemnictví v Prahe. ${ }^{11}$ Vo vel'kej miere odzrkadliujú

6 HARPÁŇ, Michal: Premeny rozprávania. Nový Sad: Obzor, 1990, s. 50.

7 ŠIMKOVIČ, Alexander: Dielo Jána Čajaka. Bratislava: Vydavatelstvo SAV, 1964, s. 125.

8 Nebudeme sa tu detailnejšia zaoberat jeho verejným účinkovaním po roku 1918; pars pro toto spomenieme iba niektoré. Jeho aktivita v prvých poprevratových rokoch logicky vyústila do zastávania významnej funkcie - stal sa prvým redaktorom spoločensko-politického časopisu Národná jednota (1920) a v tridsiatych rokoch aj redaktorom Nášho života (1933). Stál pri zrode fundamentálnych kultúrnych inštitúcií juhoslovanských Slovákov - slovenského gymnázia v Petrovci, petrovského Spevokolu, Hospodárskej školy, bol pri zakladaní Matice slovenskej v Juhoslávii (1932) atd’.

9 Čajak sa chcel po prevrate (presnejšie v roku 1923) v dôsledku tažkej materiálnej situácie vrátił na Slovensko; oslovil vtedy listom svojho d'alekého priatela K. Kálala, v ktorom ho prosil o vybavenie nejakého lepšie plateného učitelského miesta, písal aj na vtedajšie Ministerstvo školstva s prosbou o miesto inšpektora alebo profesora. Pozri Literární archiv Památníku národního písemnictví v Prahe (d’alej LA PNP Praha), osobný fond Karel Kálal, sign. 111/55, J. Čajak v liste K. Kálalovi zo dňa 9. 8. 1923.

10 Pozri BRTÁŇ, Rudo: Z listov Jána Čajaka staršieho. Nový život 25, 1973, č. 5, s. 457-468; Desat listov z korešpondencie Jána Čajaka. Nový život 15, č. 3, 1963, s. 190-194; KOVAČEK, Božidar: Ján Čajak a Matica srbská. Nový život 15, 1963, č. 3, , s. 181-189. Ján V. Ormis v úvode Súpisu prác Jána Čajaka uvádza autorovo svedectvo o tom, ako mu matka a manželka v roku 1914, ked’ bol internovaný, okrem iného spálili aj korešpondenciu.

11 V LA PNP v Prahe je z korešpondencie J. Čajaka s K. Kálalom a M. Kálalom zachovaných devät listov z rokov 1922-1926 a jedna fotografia, s A. Heydukom tri listy a jedna pohladnica z rokov 1913-1914 a s J. Svítilom Kárníkom sedem listov a jedna fotografia z rokov 1917-1935. Za sprostredkovanie týchto 
Čajakovo zmýšlanie a jeho názory na spoločensko-politické, kultúrne a jazykové dianie vo Vojvodine i na Slovensku pred rokom 1918 a potom i po prevrate, ako aj jeho pozíciu národovca mimo hlavných kultúrnych centier. Listy, ktoré písal Karlovi Kálalovi (18601930) a jeho synovi Miroslavovi Kálalovi (1893-1962), Adolfovi Heydukovi (1835-1923) a Josefovi Svítilovi Kárníkovi (1870-1958), ${ }^{12}$ dotvárajú nielen obraz historických pomerov v danom období, ale vd’aka značnej pisatel’ovej sebareflexii sú výpoved’ou aj o jeho osobnostnom profile. Je zaujímavé sledovat', aký otvorený a horlivý bol Čajak v rámci tohto epištolárneho diskurzu. Kým v niektorých otázkach bol až radikálny, na iných miestach sa zas štylizoval do pozície marginalizovaného intelektuála, ktorého mienka nemá v širších kontextoch vel'kú váhu: „Som skromným, tichým pozorovatelom, ktorý ale neprestane s láskou a zaujatostou sledovat' vývin našich mladých slavianských dřžav i národov. "13

Z korpusu listov s predstavitel'mi českého slovakofilského hnutia z konca 19. a prvých desaṫročí 20. storočia je najrozsiahlejšia korešpondencia s Karlom Kálalom (ide o už vyššie spomínaných devät zachovaných listov). Práve Kálal ako jediný, okrem Alberta Pražáka, reagoval na výzvu Čajakovho syna Jána Čajaka mladšieho prispieṫ v roku 1924 do časopisu Svit, ktorého druhé číslo malo byt venované šesṫdesiatinám jeho otca. ${ }^{14}$

\section{Slovakofil Karel Kálal}

Spisovatel', publicista a pedagóg Karel Kálal ${ }^{15}$ strávil čast’ svojho života na Morave, vo Frenštáte pod Radhoštěm (v období 1885-1904), odkial' podnikal pravidelné cesty na Slovensko. To iniciovalo jeho celoživotný záujem o slovenské otázky. Angažoval sa v propagovaní česko-slovenskej vzájomnosti - organizoval prednášky, sprostredkovával spoluprácu medzi slovenskými a moravskými osvetovými pracovníkmi, usporadúval akcie na podporu slovenských študentov, vydával knihy o Slovensku. Dôležitá je aj jeho lexikografická činnost. ${ }^{16}$

informácií d’akujeme prof. PhDr. Jaromírovi Lindovi, Ph.D. Údaje o archívnom uložení sú dostupné na internetovej stránke www.badatelna.eu.

12 Josef Svítil (pseudonym Jan Kárník či Karník) bol vojenský lekár, ale i spisovatel, publicista a slovakofil. Pripravil české edície M. Kukučína a S. H. Vajanského, písal články a úvahy o Slovensku, vydal knihu Duch Slovenska s cielom oboznámit Čechov so slovenskou literatúrou. J. Čajak v liste J. Svítilovi Kárníkovi zo dňa 24. 12. 1933 (LA PNP v Prahe, osobný fond Josef Svítil, sign. 24/76) odkazuje na svoj príspevok $Z$ mojej staršej korešpondencie v časopise Elán, 1932, č. 10, ktorý tam celý cituje a kde píše: „Druhý raz zase žiada [J. S. Kárník od J. Čajaka - pozn. Z. Č.] informáciu o literárnych pomeroch na Slovensku. ,Direktni styk s Vaši domovinou je velmi obtižný a mně jako vojenskému lékaři nemožno na Slovensko zajet, ač bych rád. Je třeba u nás zájem o Slovensko ustavične udržovati. ' Ťažko mi bolo jeho žiadosti vyhoviet' [...] od Slovenska boli sme odrezani, takže som nebol dostatočne informovaný." Spolu s K. Kálalom mu mal sprostredkovat’ vydanie románu Rodina Rovesných v Šimečkovom nakladatel'stve v Prahe, ale k tomu nedošlo.

13 LA PNP Praha, osobný fond Karel Kálal, sign. 111/55, J. Čajak v liste K. Kálalovi zo dňa 13. 11.1922.

14 Ide o krátky obligátny text najprv so slovami uznania a s adresovanou otázkou: „Nech povie, prečo Slováci upadli do poddanstva?" Pozri KÁLAL, Karel: Ján Čajak (k 60. narodeninám). Svit 2, 1924, č. 2, s. 51.

15 Podrobnejšie údaje o jeho živote pozri ŠULCOVÁ, Andrea: Karel Kálal (1860-1930). Materiální a myšlenkový svět příslušnika „stredni vrstvy“ na prelomu 19. a 20. století. In: Paginae historiae. Sborník Národního archivu 15. Praha: Národní archiv, 2007, s. 11-17.

16 K. Kálal v spolupráci s K. Salvom vydal diferenciačný Slovnik slovenskočeský a československý (1896), ktorému odborná verejnost’ pripisuje nielen dobovú, ale aj vývinovú hodnotu a podla A. Zelenkovej tu uznal slo- 
Pri tejto práci sa zblížil s mnohými podobne zmýšlajúcimi kultúrnymi činitelmi na oboch stranách (K. Salva, D. Makovický, T. Vansová, J. Kalus, A. Heyduk, T. G. Masaryk a iní). ${ }^{17}$ J. Čajak sa spoznal s K. Kálalom prostredníctvom Karola Salvu, ${ }^{18}$ ako to uvádza v liste, v ktorom sa mu po rokoch pripomínal súbežne s prosbou o spoluprácu: „Drahý priatelu! Neviem, pravda, či sa ešte pamätáte na mňa, je tomu už viac ako 30 rokov ako sme sa zišli u nášho spoločného priatel’a Karola Salvu v Ružomberku. Uňho sme sa spoznali. Vy potom ste ma vyzvali, aby som napísal niečo do Domu a školy [...]. Aj som bol napisal, myslím dva článočky, a ony boli prvé tlačené odo mřa práce." 19

K upevňovaniu česko-slovenskej vzájomnosti prispieval K. Kálal najmä početnými prácami o sociálnych a národnostných pomeroch na Slovensku (napr. Obrázky spod Tater, Z hor a plání), tiež prácami vlastivednými (Slovensko a Slováci, Slovenské pohledy) a historickými (Přehled slovenských dějin), ${ }^{20}$ ktoré spravidla vychádzali v Čechách, s cielom vzbudit tamojší záujem o Slovensko a podnietił realizáciu kultúrnej, osvetovej a materiálnej pomoci. V otázke jazyka zastával liberálnejšie stanovisko: „Jsem pro dvě spisovná nářeč př́ jednotné kultuře československé. “21 Jeho prístup z odstupu času zhodnotila Anna Zelenková nasledovne: „Obojstranná vzájomnost’ podla neho nespočívala v jednotnom spisovnom jazyku, ale v rovnocennej výmene kultúrnych hodnôt a v politickej, kultúrnej, dokonca aj národnostnej jednote. "22 Kálalovo vnímanie, že česko-slovenská vzájomnost̉ by bola prínosná aj pre Čechov „vzhl'adom na silnejšie odolávanie nemeckému a mad'arskému tlaku v strednej Európe, pretože by [to - pozn. Z. Č.] posilnilo spoločnú národnú identitu a politický vplyv" ${ }^{23}$ dopíňala

venčinu ako autonómny jazyk. Porov. GAJDOŠOVÁ, Katarína: Slovensko-česká a česko-slovenská dvoijazyčná lexikografia. Vývinový prehlad od 19. storočia po súčasnost. Čast I. Slovenská reč 79, 2014, č. 5-6, s. 274-303. D̆alej porov. ZELENKOVÁ, Anna: Medzi vzájomnostou a nevzájomnostou. Op. cit., s. 81. Na toto lexikografické dielo s otcovou pomocou nadväzuje M. Kálal v Slovenskom slovniku z literatúry aj nárečí (Slovensko-český differenciálny). Na základe slovnikov, literatúry aj živej reči (1923). Mimochodom, v slovníku sa nachádzajú aj jednotlivé nárečové slová z Báčky, ktoré mu zasielal Ján Čajak. Ten slovník ocenil slovami: „Prezrel som letkom Vaše dielo. Obdivujem Vašu mravčiu pilnost.' Velikú medzeru ste zaplnili. Pomocou Vášho slovnika prístupnejšimi ste urobili širšiemu obecenstvu naše literárne diela, hlavne ale Hviezdoslavove. Obohatili ste znanie slov. jazyka a objavili ste z velkej čiastky aj bohatost’ jeho." LA PNP Praha, osobný fond Karel Kálal, sign. 111/55, J. Čajak v liste K. Kálalovi zo dňa 19. 6. 1926. Na Kálalovo lexikografické dielo neskôr úspešne nadväzoval jeho syn, filológ a stredoškolský profesor Miroslav Kálal (1893-1962), ktorý pôsobil v Banskej Bystrici.

17 Porov. heslo Karel Kálal. In: Lexikon české literatury 2/II, K-L. Praha: Academia, 1993, s. 616-618. Ďalej porov. ZELENKOVÁ, Anna: Medzi vzájomnostou a nevzájomnostou. Sondy do česko-slovenských a slovensko-českých literárnych vztahov. Praha - Nitra: Slovanský ústav AV ČR - Filozofická fakulta Univerzity Konštantína Filozofa v Nitre, 2009, s. 80-81.

18 K. Salva bol učitel', neskoršie vo vlastnej tlačiarni vydával v období najsilnejšej mad’arizácie kalendáre v tisícových nákladoch, ako aj interkonfesionálny pedagogický časopis Dom a škola, s podnázvom Vychovávatel'ský časopis pre rodičov a učitelov (1885-1897), ktorý prinášal popularizačno-vedecké a osvetové články, články z didaktiky a metodiky vyučovania, z dejín svetovej pedagogiky a pod. Od roku 1897 sa jedným z jeho redaktorov stal aj K. Kálal. Časopis propagovali aj na Morave a v Čechách.

19 LA PNP Praha, osobný fond Karel Kálal, sign. 111/55, J. Čajak v liste K. Kálalovi zo dňa 22. 10. 1922.

20 Niektoré z uvedených prác nájdeme na https://zlatyfond.sme.sk/autor/253/Karel-Kalal.

21 KÁLAL, Karel: „S ideou československé vzájomnosti..." Prúdy 5, 1914, č. 9-10, s. 545. Dostupné na http:// digitalna.kniznica.info/zoom/84686/view

22 ZELENKOVÁ, Anna: Medzi vzájomnostou a nevzájomnostou. Sondy do česko-slovenských a slovensko-českých literárnych vztahov. Op. cit., s. 81.

23 Tamže, s. 80. 
predstava, že práve Slovensko by malo byt mostom k Rusku. ${ }^{24}$ Pritom Slovensko bolo podla Kálala životne závislé od spolupráce s českým prostredím: „Pro Čechy je československá vzájemnost velkou posilou, pro Slováky životni podminkou. " 25

Krátko po vzniku Československej republiky Kálal ako pracovník slovenského oddelenia rezortu odborného vzdelávania Ministerstva školstva a národnej osvety odišiel do Banskej Bystrice, kde organizoval ludovýchovnú činnost’ a propagoval česko-slovenskú vzájomnost̉ aj medzi nižšími spoločenskými vrstvami. V súdobej slovenskej spoločnosti to ale čoraz viac, aj v súvislosti s nárastom autonomistických nálad, narážalo na odpor. Ako uvádza Andrea Šulcová, „svými výroky o vzájemném poměru českého a slovenského národa, ve kterých neprestával Slováky paternalisticky označovat za, mladšího, méně zkušeného, chudšiho bratra', si proti sobě popudil jak slovenské politické deniky, tak i některé své někdejši přátele na Slovensku“ “. ${ }^{26}$ Pre tieto okolnosti a tiež pre zhoršený zdravotný stav sa napokon v roku 1923 rozhodol pre návrat do Prahy.

K zásadným názorom K. Kálala na podoby česko-slovenskej spolupráce a vzájomnosti sa v mnohom prikláňal aj Ján Čajak. ${ }^{27}$

\section{K otázke česko-slovenskej vzájomnosti u Jána Čajaka ${ }^{28}$}

Jána Čajaka viedli k literárnej tvorbe vo vel'kej miere l’udovýchovné snahy, ${ }^{29}$ čo sa najčastejšie dávalo do súvislosti s ideológiou hlasistov, ktorí hlásali česko-slovenskú spoluprácu. ${ }^{30}$ Už Andrej Mráz však zdôraznil, že Čajak „pri všetkých styčných bodoch, ktoré mal s tou

24 Tamže. Porov. KÁLAL, Karel: Vzájomnost’ československá. In: Od Šumavy k Tatrám. Ružomberok: Knihtlačiareň Karla Salvu, 1898. Dostupné na: https://zlatyfond.sme.sk/dielo/5076/Kalal_Od-Sumavy-k-Tat$\mathrm{ram} / 16$.

25 KÁLAL, Karel.: „S ideou československé vzájomnosti...“ Prúdy 5, 1914, č. 9-10, s. 544. Dostupné na http:// digitalna.kniznica.info/zoom/84686/view.

26 ŠULCOVÁ, Andrea: Karel Kálal (1860-1930). Materiálni a myšlenkový suět př̌slušníka „středni vrstuy“ na prelomu 19. a 20. století. Op. cit., s. 16.

27 Ako príklad podobných ideových názorov môžeme uviest̉ myšlienku o českom národe ako staršom bratovi vo vztahu k slovenskému národu: „Hej, viem ja dobre, že ste Vy vyspelejši, dôslednejší, trpezlivejši a vytrvalejši ludia, ktorí pevne idú za svojím cielom a ktorís ludimi nám rovnými (horkokrvnými a viac citnými ako rozumnými) zaobchádzate s trpezlivostou a istou pedagogickou zhovievavostou, nuž tak ako opravdivi verni starši skúsenejši bratia s mlaď̌im ešte nedospelým bratom." LA PNP Praha, osobný fond Josef Svítil, sign. 24/76, J. Čajak v liste J. Svítilovi Kárnikovi zo dňa 15. 7. 1918.

28 Základným prameňom pre spracovanie tejto témy sú Čajakove listy K. Kálalovi, z nich najmä 20-stranový list, kde Čajak iniciuje opätovný kontakt s K. Kálalom, nazývajúc ho „apoštolom, ktorý si vytkol za životný ciel' pomáhat' ubitému národu" a vel'mi obšírne reaguje na jeho články, najmä na článok Jeden či dva národy? uverejnený v Slovenskom denníku v roku 1922. Tento článok vyvolal na Slovensku velký ohlas. Niektoré reakcie z novín Slovenský denník a Považské hlasy sú dostupné na: http://digitalna.kniznica.info/ zoom/84686/view.

29 Celú jednu skupinu jeho literárnych diel charakterizujú didaktické, mravoučné a osvetové zretele, najvýraznejšie je to v poviedke Suchoty (1908), kde sleduje ludovýchovný program blízky hlasistom, čo bolo ovplyvnené jeho celoživotným pôsobením medzi ludom.

30 Ideológia hlasizmu sa formovala okolo časopisu Hlas (1898-1904, redaktor Vavro Šrobár) ako reakcia na národnú koncepciu martinského centra. Zástancovia hlasistického programu vychádzali aj z Masarykových filozofických a ideologicko-politických názorov (napr. filozofia drobnej osvetovej práce) a hlásali 
alebo onou ideovou a politickou orientáciou u nás [na Slovensku - pozn. Z. Č.], nepridával sa dogmatársky k jednému prúdu, ale s charakternou odvahou osobnostne vyrovnával sa s problémami a svoj postoj k ideám a veciam formoval si po zodpovednom kritickom skúmani". ${ }^{31}$ Hlasistický program v ňom len upevnil jeho vlastné názory a presvedčenie, formované a životom prehodnocované - počnúc štúrovským programom cez vlastné zápasy s mad’arizáciou až po neskoršie zapájanie sa do národného života vojvodinských Slovákov po príchode do Báčky.

Kontakty so Slovenskom nechcel Čajak prerušit, o čom svedčí napríklad práca Prehl'ad súčasnej slovenskej literatúry, ${ }^{32} \mathrm{v}$ ktorej sleduje snahu ,populárnym spôsobom srbským čitatelom prezentovat' súčasnú slovenskú literatúru, a tak predovšetkým prispiet' $k$ upevňovaniu pocitu vzájomnej spolupatričnosti a solidarity Slovákov a Srbov v boji za ich národné práva v Rakúsko-Uhorsku“. ${ }^{33}$ Prehl'ad... však ukázal aj na Čajakovu nedostatočnú rozhl'adenosṫ v súdobom literárnom dianí na Slovensku (preferoval tvorbu Vajanského a najmä Hviezdoslava, a nedocenil tvorbu mladšej realistickej generácie). Obdobná situácia je aj v jeho reflektovaní dobových spoločensko-politických pomerov na Slovensku, resp. v Československu po roku 1918: jeho názory na česko-slovenskú vzájomnosť a československú národnú jednotu odzrkadlujú postoj slovenského intelektuála sformovaného v období národnej neslobody a po prevrate vzdialeného od spoločensko-politického a kultúrneho diania, ale zároveň aj jeho úsilie byt v kontakte s materskou krajinou a s dianím v nej (tak literárnym, ako aj spoločensko-politickým).

Čajak vnímal československú národnú jednotu v dvadsiatych rokoch 20. storočia ako záchrannú ideu v súdobom geopolitickom usporiadaní Európy so silnejúcimi nacionalistickými tendenciami. V roku 1922 píše K. Kálalovi: „Nevýsloune ma bôlne dotkýna sa nesmierna zášt', ktorá panuje na Slovensku proti Čechom. Je to vol'ačo hrozného, neslýchaného. Viem, že velmi mnoho zapričinila i tá vrstva Čechov, ktorá nebola na výške svojho poslania, ale $i$ to viem, že akú sebaobetavú a úmornú prácu, a to blahodarnú konali a konajú i teraz na Slovensku. Som v tom úplne presvedčený, že Slovensko by nebolo sa v stave udržat’ bez nich ani len za mesiac. [...] Poneváč som synom slovenského národa a celý život prešiel mi v práci na jeho

česko-slovenskú vzájomnost̉ a spoluprácu, čo sa však v rovine etnoemancipačných snáh Slovákov javí ako nedemokratické, ako o tom píše napr. aj Michal Gáfrik: „Česká‘ orientácia hlasistov v ich politike, publicistike a kultúre v skutočnosti znamenala vzdanie sa slovenskosti, čsko-slovenské národné splynutie, čechoslovakizmus. "Pozri GÁFRIK, Michal: Martin a hlasisti. In: Proti noci. Výber z publicistiky. Martin: Matica slovenská, 2003, s. 25. J. Čajak hlasistický program zrodený v českom prostredí hodnotil kladne: „K pozorovaniu každodenných potrieb národa $i k$ praktickej politike nás priviedli Česi. Na českých vysokých školách vždy sa našlo niekol’ko slovenských študentov. $Z$ týchto niektori prizerali sa bližšie, že ako sa pracuje v Čechách na poli národnom. I poučili sa tam, že treba pracovat’ na mravnom obrodeni slovenského ludu [...]. Roku 1896 zišla sa mládež slovenská v Martine počas výročných slávností a tam si ustálila program. " Cit. podla ČAJAK, Ján: Dejepis Slovákov. Báčsky Petrovec: Slovenské vydavatelské centrum, 2014, s. 152. Úsilie hlasistov kladne zhodnotil aj v liste K. Kálalovi zo dňa 12. 11. 1922, ktorý je uložený v LA PNP v Prahe, osobný fond Karel Kálal, sign. 111/55: „Hnutie Hlasistov na Slovensku a ich kritika vyvolala celú búru v našom nár. živote, ale rozprúdila život, zburcovala národ z pasivity a úspechy vidné tak v politickom, ako aj v hospodárskom živote nevystali."

31 MRÁZ, Andrej: Realistický prozaik Ján Čajak. In: Rozhovory o vojvodinských Slovákoch 1. Báčsky Petrovec: Kultúra, 2004, s. 99.

32 Prehlad bol uverejnený v srbčine v troch pokračovaniach v Letopise Matice srpske v rokoch 1905 a 1906.

33 SVETLÍK, Adam: Premeny literárnej kritiky vojvodinských Slovákov. Báčsky Petrovec: Slovenské vydavatelské centrum, 2015, s. 34. 
vzdelávani, nuž to sa rozumie, že i teraz, ked' som odtrhnutý od neho, dušou i telom som s ním, zaň cítim a obávam sa o jeho budúcnost'. Cítim a viem, že slovenský, tak aj český národ spasi a zabezpeči len jedna myšlienka, idea, len ked' sa budú jedným nerozlučným národom cítit' a ked' si budú vytvárat', zdokonal'ovat' jednu celistvenú vlast', dřžavu v podobe terajšej Československej republiky, len vtedy môže sa táto v tak neprajnom geografickom položení sa nachádzajúca, udržat." "34 Dokladá to aj obrazným prirovnaním: „Jestli v tejto dobe nepresiakne do najširších vrstiev tak Čechov, ako i Slovákov, jednotná idea, jednotná snaha i sila národa, tak celé vybudovanie štátu bude ako ten starozákonný obraz, ktorý mal zlatú hlavu, železné prsia, ale hlinené nohy. "35 Ako vyplýva z jeho korešpondencie, jeho obavy sa vztahovali na opätovné možné „porobenie“ Slovákov zo strany Mad’arov, čo sa podla neho mohlo stat', ak sa osamostatnia a odtrhnú od Čechov. Aj ked’ národ nestotožňuje so štátom, domnieva sa, že bez štátu budú Slováci vystavení napospas Mad’arsku a hrozí im asimilácia a zánik. Preto i autonomistické úsilia niektorých slovenských politikov v dvadsiatych rokoch 20. storočia hodnotil vel'mi negatívne: „Autonómia znač pruý krok preč od Prahy, preč od bratského českého národa. "36 Podl’a jeho názoru autonomistické snahy boli úzko späté s klerikalizmom, spoločne ohrozovali nielen nový spoločenský poriadok, ale aj existenciu nových štátov, ako boli Československá republika a Královstvo Srbov, Chorvátov a Slovincov: „Klerikalizmus pre nás to isté znamená čo i komunizmus. I jedno, i druhé pre nás znamená smrt."37 Práve československá národná jednota, budovaná na vzájomnej tolerancii, bola podla Čajaka garantom, že sa to nestane: „Nie autonómia, ale obapolné poctivé dohodnutia a úplná rovnoprávnost." ${ }^{38}$ Rozkol medzi Slovákmi a Čechmi nazýva na inom mieste trhlinou a obáva sa, že prerastie do priepasti, nad ktorou bude tažko „vymurovat klenbu“. 39

$\mathrm{S}$ ideou československej jednoty je úzko prepojená otázka národného jazyka. ${ }^{40} \mathrm{Zmier}$ ňujúce a kompromisné stanovisko v chápaní komplexných česko-slovenských vztahov, ktoré majú prebiehat’ predovšetkým v rovine osvety (vzdelávania, kultúry, literatúry) teda v rovnakom duchu, ako to videl napr. K. Kálal -, Čajak premieta aj do jazykovej otázky: „My Slováci sme sa ale od Čechov ani vtedy neodtrhli, lebo ked' sme sa rečove i oddialili od Čechov, to sme preto urobili, aby sme sa lepšie, zrozumitel’nejšie mohli približit’ ku svojmu vlastnému l'udu. "41 Zdôrazňovanie pragmatickej funkcie kodifikácie slovenského jazyka, čo je

34 LA PNP v Prahe, osobný fond Karel Kálal, sign. 111/55, J. Čajak v liste K. Kálalovi zo dňa 12. 11. 1922.

35 Tamže.

36 Tamže.

37 Tamže.

38 Tamže.

39 Pozri text Rozháranost'. Národná jednota 2, 1921, č. 9, s. 1-2. Aj ked' je text nepodpísaný, na základe štylizácie podobných myšlienok v danom texte a v listoch K. Kálalovi je možné usudzovat', že jeho autorom bol pravdepodobne J. Čajak. Navyše, je to úvodník, ktorý spravidla písal redaktor časopisu - tým bol v danom čase práve Čajak.

40 J. Čajak vo svojich prejavoch často používal bohemizmy, čo podla vojvodinského slovakistu Michala Filipa malo za ciel' zamedzit prienik inorečových prvkov do slovenského jazyka. Ďalším dôvodom bola rozkolísanosṫ dobovej jazykovej normy. Pozri FILIP, Michal: České jazykové prvky v tvorbe Jána Čajaka. In: Štúdie a články. Nový Sad: Obzor-Tvorba, 1990, s. 73-82.

41 ČAJAK, Ján: Dejepis Slovákov. Báčsky Petrovec: Slovenské vydavatel'ské centrum, 2014, s. 98. (Práca pôvodne vyšla v Pittsburghu v USA v roku 1914.) 
zároveň i podpora Štúrovej jazykovej „odluky“, môžeme dat do súvisu s ludovýchovnou prácou - osveta l’udu sa môže konat̉ iba v jemu zrozumitelnom jazyku.

Ako jeden z účastníkov ankety v časopise Prúdy v roku 1914 o československej vzájomnosti, kde na otázky odpovedali mnohí kultúrni a spoločenskí pracovníci, okrem iných takisto K. Kálal a J. Svítil Kárník, Čajak vyjadruje svoj názor takto: „S myšlienkou československej vzájomnosti súhlasím. Predstavujem si ju ako spojítko kultúrne a hospodárske." ${ }^{2}$ Jeho postoj ohladom jazyka sa vyvíjal, ale podstatne sa nemenil. Najprv to bola jednoznačná podpora slovenčine, so želaním, aby z toho i čeština „skrásnela“: „Ani mi do umu nepríde, aby vzájomnost' mala byt’ na úkor slovenčiny. Práve naopak, od styku tohoto očakávam ustálenie pravopisu a vykryštalizovanie nášho jazyka. Áno, pri tomto styku čeština tiež zle neobíde, i ona bude mat' príležitost' sa okrášlit’ zo skvostov našej reči. A ked’ by i na to prišlo, žeby náš jazyk podl'ahol, ̌́ je však vylúčená vec, bolo by predsa lepšie, ked’ by sa vtopil do jazyka takého blizkeho. "43 Československá národná jednota teda pre Čajaka neznamenala súbežne aj jazykové splynutie: „Jednotu národa nepovažujem za splynutie sa i rečovite. To by som ponechal - $i$ má sa ponechat' - prirodzenému vývinu v budúcnosti. [...] O počěsteni, vlastne o vytisnuti slovenčiny sa nebojim. To je ani nie potrebné. Hlavná vec je, aby povedomie spolužitia, odkázanosti jeden na druhého bolo širené zovšeobecnene. V tomto má väziet' jednota národa. Či istá čast' hovorí $z$ neho česky či slovensky, to je druhotriedna vec, hlavné je, aby sme si upovedomili, že sme deti jednej matky a pritomnost' i budúcnost' naša nám je len tak zabezpečená, jestli vzájomnost' pestujeme, a tým štát upevňujeme." ${ }^{44}$

V súvislosti so Štúrovou kodifikáciu slovenského spisovného jazyka a chápania tohto činu ako trieštenia československej jednoty (zo strany J. Kollára, P. J. Šafárika a iných) písal: „Ked' nestranne pozeráme na tento boj, tak musíme uznat', že obe stránky mali pravdu. Štúr a jeho prívrženci turdili, že len rodným jazykom je možné zbliženie k l'udu a mu osvetu podat', lebo že československý jazyk mu je nie tak blizky a zrozumitelný. Akže teda chceme národne uvedomit' a povzniest' l’ud, musime v jeho reči pisat’ a hovorit'. Kollár a jeho priatelia sa zase báli, že ak sa Slováci odtrhnú rečove od Čechov, že zoslabnú, lebo že sa netreba trhat', ale jednotit. V tomto bolo mnoho pravdy. My aj teraz musime hl'adat'zbliženie s bratmi Čechmi, čo aj nie rečove, ale osvetove a od nich čerpat' $i$ vedomosti, $i$ posilu. Učit' sa z ich spisby a osvojit' si ich kultúru, ako nám najbližšiu a najrodnejšiu. Tým činom sa upevníme a vzdeláme, bez toho, aby sme upadli do nebezpečia národného zahynutia. "45

Aj ked' prvenstvo spravidla patrilo Čechom, čo Čajak posúva niekedy až do romantizujúcich a idealizujúcich polôh, v Dejepise Slovákov - v kapitole Styky českého národa so Slovákmi - neobchádza ani význam príslušníkov slovenského národa a prostredia pre českú kultúru: „Ináče Slováci vždy vyznávali aj vyznávajú bratskú spolupatričnost’ ku Čechom i spoločnú kultúru. Ved'spoločnú kultúru máme, toho dôkazom je, že my sme dali Čechom Kollára a Šafárika, dvoch najuäč̌́ich našich aj ich mužov, taktiež v slovenskom kruhu vychovaný bol ich

42 J. Č. [= ČAJAK, Ján]: „S myšlienkou československej vzájomnosti...“ Prúdy 5, 1914, č. 9-10, s. 542-544. Dostupné na http://digitalna.kniznica.info/zoom/84686/view.

43 Tamže, s. 543.

44 LA PNP Praha, osobný fond Karel Kálal, sign. 111/55, J. Čajak v liste K. Kálalovi zo dňa 9. 10.1922.

45 ČAJAK, Ján: Dejepis Slovákov. Op. cit., s. 98. 
najuäč̌si muž, ,otec národa“ Palacký.“"46

Idea československej vzájomnosti a národnej jednoty bola u Čajaka základom jeho celoživotného literárneho a spoločenského pôsobenia. Aktualizoval ju najmä po rozpade Rakúsko-Uhorska v roku 1918 a vzniku jeho nástupníckych štátov. Domnieval sa, že Slováci a Česi sa v danom geopolitickom priestore Európy so silnejúcimi nacionalistickými tendenciami udržia len rozvíjaním česko-slovenskej vzájomnosti. Vzájomnost̉ vnímal ako národnú jednotu - kultúrnu, osvetovú, literárnu a hospodársku spoluprácu dvoch bratských národov, v ktorej však prvenstvo patrí Čechom. V otázke jazyka sa priklonil k zástancom Štúrovej jazykovej „odluky“, a to z ideových a pragmatických dôvodov, aj pod vplyvom hlasistickej ideológie, pritom v budúcnosti nevylučoval možnost jazykového splynutia, resp. zblíženia, aj ked’ sa mu to zdalo dost’ nepravdepodobné.

Čajakovu osobnost' a jeho celoživotný zápas o národné veci poznačilo vedomie zodpovednosti za osud národa, také typické pre staršie, ideologicky (a mimoliterárne) motivované chápanie spisovatel’a ako reprezentanta národa: „Každý väăší, či menši pracovník a činitel' národný je zodpovedný nielen sám sebe v terajšom čase, ale je zodpovedný celému národu i budúcim pokoleniam. Na dačo súci človek má mat’ tol'kú snahu, aby ho budúce pokolenie po dobrom spominalo a je zodpovedný a bude zaznamenaný $i v$ dejinách národa a republiky. "47 Napriek tomuto úsiliu bol J. Čajak ako literát často podceňovaný a neskôr zabúdaný - Andrej Mráz o tejto skutočnosti už v roku 1944 napísal: „Aj po svetovej vojne nakladatel'stvá ochotne vydávali Čajakove spisy, no nemôžeme sa zbavit’ dojmu, že vo všetkom tomto kladnom prijimani dolnozemského spisovatel'a, vždy bola istá rezerva, istá zhovievavost' a sentimentálna zainteresovanost’ o autora, ktorý je z radov vyst’ahovaleckých príslušnikov nášho národa." 48 Takýto dištanc k jeho dielu však v slovenskom prostredí pretrváva dodnes.

\section{Pramene}

Literární archiv Památníku národního písemnictví Praha, osobné fondy: Karel Kálal, Josef Svítil.

BRTÁŇ, Rudo: Desat' listov z korešpondencie Jána Čajaka. Nový život 15, 1963, č. 3, s. 190-194.

BRTÁŇ, Rudo: Z listov Jána Čajaka staršieho. Nový život 25, 1973, č. 5, s. 457-468.

ČAJAK, Ján: Dejepis Slovákov. Báčsky Petrovec: Slovenské vydavatel’ské centrum, 2014.

J. C̆. [= ČAJAK, Ján]: „S myšlienkou československej vzájomnosti...“ Prúdy 5, 1914, č. 9-10, s. 542-544. Dostupné na http://digitalna.kniznica.info/zoom/84686/view, prístup 28. 10. 2018.

KÁLAL, Karel - KÁLAL, Miroslav: Slovenský slovnik z literatúry aj náreči (Slovensko-český differenciálny). Na základe slovnikov, literatúry aj živej reči. Banská Bystrica: nákladom vlastným,1923.

KÁLAL, Karel: Vzájomnost’ československá. In: Od Šumavy k Tatrám. Ružomberok: Knihtlačiareň Karla Salvu, 1898. Dostupné na: https://zlatyfond.sme.sk/dielo/5076/Kalal_Od-Sumavy-k-Tat$\mathrm{ram} / 16$.

46 Tamže, s. 155.

47 LA PNP Praha, osobný fond Karel Kálal, sign. 111/55, J. Čajak v liste K. Kálalovi zo dňa 12. 11. 1922.

48 MRÁZ, Andrej: Realistický prozaik Ján Čajak. Op. cit., s. 91-133. 
KÁLAL, Karel: „S ideou československé vzájomnosti... “ Prúdy 5, 1914, č. 9-10, s. 545. Dostupné na http://digitalna.kniznica.info/zoom/84686/view.

KÁLAL, Karel: Ján Čajak ( $k$ 60. narodeninám). Svit 2, 1924, č. 2, s. 51.

Rozháranost'. Národná jednota 2, 1921, č. 9, s. 1-2; nepodpísané.

\section{Literatúra}

ČEPAN, Oskár: Stimuly realizmu. Bratislava: Tatran, 1984.

ČÍŽIKOVÁ, Zuzana: Slovenská vojvodinská próza: od epigónstva po paródiu. In: Imitácia - alúzia - plagiát. Nitra: Univerzita Konštantína Filozofa v Nitre, Filozofická fakulta, 2014, s. 38-49.

FILIP, Michal: České jazykové prvky v tvorbe Jána Čajaka. In: Štúdie a články. Nový Sad: Obzor-Tvorba, 1990, s. 73-82.

GAJDOŠOVÁ, Katarína: Slovensko-česká a česko-slovenská dvojjazyčná lexikografia. Vývinový prehlad od 19. storočia po súčasnost'. Čast' I. Slovenská reč 79, 2014, č. 5-6, s. 274-303.

GÁFRIK, Michal: Martin a hlasisti. In: Proti noci. Výber z publicistiky. Martin: Matica slovenská, 2003, s. 25-28.

HARPÁŇ, Michal: Premeny rozprávania. Nový Sad: Obzor, 1990.

HUČKOVÁ, Dana: Úsilie o autorskú osobitost’ v kontexte tradicie žánru (Ján Čajak: Rodina Rovesných). Slovenská literatúra 59, 2012, č. 3, s. 217-229.

KOVAČEK, Božidar: Ján Čajak a Matica srbská. Nový život 15, 1963, č. 3, s. 181-189.

Karel Kálal. In: Lexikon české literatury 2/II, K-L. Praha: Academia, 1993, s. 616-618.

KMEŤ, Ján: Čajakova umelecká osobnost’. In: Pohlady a portréty. Petrovec: Obzor, 1963, s. 37-58.

MRÁZ, Andrej: Realistický prozaik Ján Čajak. In: Rozhovory o vojvodinských Slovákoch 1. Báčsky Petrovec: Kultúra, 2004, s. 91-133.

ORMIS, Ján Vladimír: Súpis prác Jána Čajaka. In: Sborník Matice slovenskej 15, 1937, č. 4, s. 529-540.

PIŠÚT, Milan a kol.: Dejiny slovenskej literatúry. Bratislava: Obzor, 1984.

SEDLÁK, Imrich a kol.: Dejiny slovenskej literatúry I., II. Martin - Bratislava: Matica slovenská - Literárne informačné centrum, 2009.

SVETLÍK, Adam: Premeny literárnej kritiky vojvodinských Slovákov. Báčsky Petrovec: Slovenské vydavatelské centrum, 2015.

ŠIMKOVIČ, Alexander: Dielo Jána Čajaka. Bratislava: Vydavatel’stvo SAV, 1964.

ŠMATLÁK, Stanislav: Dejiny slovenskej literatúry I., II. Bratislava: Národné literárne centrum, 1999.

ŠULCOVÁ, Andrea: Karel Kálal (1860-1930). Materiálni a myšlenkový svět př́slušnika „středni vrstuy“ na prelomu 19. a 20. století. In: Paginae historiae. Sborník Národního archivu 15. Praha: Národní archiv, 2007, s. 11-17.

ZELENKOVÁ, Anna: Medzi vzájomnostou a nevzájomnostou. Sondy do česko-slovenských a slovensko-českých literárnych vztahov. Praha - Nitra: Slovanský ústav AV ČR - Filozofická fakulta Univerzity Konštantína Filozofa v Nitre, 2009.

https://zlatyfond.sme.sk/autor/253/Karel-Kalal 
Zuzana Čížiková, Dr.

Katedra slavistiky

Filologická fakulta, Univerzita v Belehrade

Studentski trg 3, 11000 Belehrad, Srbsko

z.cizikova@fil.bg.ac.rs

Toto dilo lze uží v souladu s licenčními podmínkami Creative Commons BY-SA 4.0 International (https://creativecommons.org/licenses/by-sa/4.0/legalcode). Uvedené se nevztahuje na díla či prvky (např. obrazovou či fotografickou dokumentaci), které jsou v díle užity na základě smluvní licence nebo výjimky či omezení příslušných práv. 